\title{
Effect of Helicobacter pylori infection on 24 hour intragastric acidity in patients with gastritis and duodenal ulcer
}

\author{
S Wagner, U Gladziwa, K Haruma, M Varrentrapp, M Gebel
}

\begin{abstract}
Helicobacter pylori status, gastric histology, and 24 hour acidity were studied in $\mathbf{3 5}$ gastritis patients, 21 duodenal ulcer patients, and 14 subjects with normal gastric mucosa. $H$ pylori was identified in 21 of 35 patients with chronic active gastritis and in 19 of 21 duodenal ulcer patients, but in none of those with normal gastric mucosa. Mean scores of activity of gastritis were similar in $\boldsymbol{H}$ pylori positive gastritis and duodenal ulcer patients, but were significantly lower in $\boldsymbol{H}$ pylori negative gastritis patients $(2.1(0.8)$ and $2.3(0.9) v 1.4(0.7)$; p $<0.01$, respectively). Median 24 hour hydrogen ion activity (interquartile range) was $21(8.9-38.0) \mathrm{mmol} / \mathrm{l}$ in normal subjects and 23 $(11 \cdot 2-49 \cdot 0) \mathrm{mmol} / \mathrm{l}, 19(7 \cdot 1-33 \cdot 1) \mathrm{mmol} / \mathrm{l}, 44$ $(25 \cdot 1-63 \cdot 1) \mathrm{mmol} / \mathrm{l}$, and $36(31 \cdot 6-39 \cdot 8) \mathrm{mmol} / \mathrm{l}$ respectively in gastritis and duodenal ulcer patients with and without $\boldsymbol{H}$ pylori infection. During all predefined time periods, intragastric acidity was significantly higher in patients with $\boldsymbol{H}$ pylori positive duodenal ulcers compared with gastritis patients and normal subjects. However, there was no significant difference in intragastric acidity between the $H$ pylori positive and negative gastritis patients. These results suggest that most of the subjects with chronic $H$ pylori infection have normal gastric acidity.
\end{abstract}

(Gut 1992; 33: 1024-1028)

Department of

Gastroenterology and Hepatology,

Medizinische

Hochschule Hannover,

D-3000 Hannover, 61

Germany

$S$ Wagner

M Varrentrapp

M Gebel

Department of Medicine, Rheinisch-Westfälische

Technische Hochschule Aachen, D-5100 Aachen, Germany

U Gladziwa

The First Department of Internal Medicine, Hiroshima University School of Medicine, Hiroshima 734, Japan K Haruma

Correspondence to: Dr Siegfried Wagner, Dept of Gastroenterology and Hepatology, Medizinische Gedizinisch Hochschule Hannover, Konstanty Gutschowstr 8, D-3000 Hannover 61, Federa Republic of Germany.

Accepted for publication 19 November 1991
A causative role is now generally accepted for Helicobacter pylori in type B gastritis, and evidence is accumulating that $H$ pylori infection plays a major contributory part in peptic ulcer disease. ${ }^{12}$ It has been shown that eradication of $H$ pylori is associated with a significant reduction in the duodenal ulcer relapse rate..$^{3-5}$ Since, on average, duodenal ulcer patients secrete more acid than control subjects, Levi et al have suggested that $H$ pylori causes duodenal ulcer disease by stimulating antral mucosal gastrin release which increases gastric acid secretion. ${ }^{6}$ shown in subjects infected with $H$ pylori, the effect of $H$ pylori infection on gastric acidity remains controversial..$^{7-1+}$ Acute infections may lead to a transient hypochlorhydria. ${ }^{15-18} \mathrm{By}$ contrast, in chronic infections large variations in gastric acidity have been reported, including hypochlorhydria, hyperchlorhydria, and normal acid secretion. ${ }^{6-1+19}$ There is, however, a paucity of data relating gastric acidity to the presence of chronic $H$ pylori infection. Because of this we have studied the effect of gastric $H$ pylori infection on the circadian pattern of While inappropriate hypergastrinaemia has been gastric acidity in patients with gastritis and active duodenal ulcer disease.

\section{Methods}

\section{STUDY SUBJECTS}

Informed consent was obtained from each subject taking part in this study, in accordance with the declaration of Helsinki (1964) as revised in Tokyo (1975). Adult patients undergoing upper gastrointestinal endoscopy for routinely accepted clinical indications were considered for entry into the study if endoscopy showed a duodenal ulcer, gastritis, or normal mucosa. Routine biopsies were performed when indicated. For the study, separate biopsy specimens were obtained from the lesser curve of the antrum for the detection of $H$ pylori and for histopathological classification..$^{20} 21$ The subjects were finally categorised into three groups according to their endoscopic and histopathological findings as follows: (i) active duodenal ulcer (endoscopic diagnosis); (ii) gastritis (histologically classified ${ }^{21}$ ); and (iii) normal (if both endoscopy and histology were normal). The subjects did not have complications of peptic ulcer disease; previous gastric surgery; concomitant treatment with ulcerogenic drugs, anticoagulants, or antibiotics; or any serious chronic disease. Only patients who had had no antibiotic treatment in the previous six months were included. Gastritis patients who had a medical history of ulcers were excluded.

\section{ENDOSCOPY}

At each endoscopy (Olympus GIF Q 20, Olympus Corp) at least five biopsy specimens were taken with sterilised biopsy forceps from the antral mucosa. Two specimens were placed in $2 \mathrm{ml}$ phosphate buffered saline at $4^{\circ} \mathrm{C}$ for bacteriological examination, two were fixed in $10 \%$ formalin for histopathology, and one specimen was used for a rapid urease detecting test (CLO-test, Delta West Ltd, Australia). In addition, smears of biopsy specimens were made for cytological examination using Giemsa staining.

\section{H PYLORI SCREENING}

$H$ pylori status was assessed by bacterial culture, a modified Giemsa stain, and the CLO-test as described previously. ${ }^{2021}$ Two biopsy specimens were cultured for seven days under microaerobic conditions in blood agar base containing 5\% horse blood and Skirrow selective supplement. Cultures were considered positive for $H$ pylori 
if Gram negative, oxidase positive, catalase positive, and urease positive spiral rods were present. The degree of colonisation with $H$ pylor was estimated by examination of sections and smears stained with Giemsa and was graded semiquantitatively. $H$ pylori status was regarded as positive if the culture was positive and/or if the urease test and Giemsa stain were positive. ${ }^{21}$

\section{HISTOPATHOLOGY}

For histological examinations formalin fixed biopsy samples were embedded in paraffin and $4 \mu \mathrm{m}$ sections were stained with haematoxylineosin and Giemsa. Each biopsy specimen was assessed for the presence, type, density, and localisation of the inflammatory infiltrate. The degree of activity of gastritis was graded by estimating the density of polymorphonuclear leukocyte infiltrates as described previously. ${ }^{21}$ Gastritis scores of $H$ pylori positive patients and of uninfected patients were compared using Student's $t$ test.

\section{GASTRIC PH MONITORING}

Gastric acidity was measured within three days of endoscopy. Intragastric $\mathrm{pH}$ was measured with a combined glass electrode (Ingold type 440 M4, Ingold AG, Urdorf, Switzerland) connected to a portable solid state recorder (Digitrapper 6200 MII, Synectics Medical, Stockholm, Sweden) as described recently. ${ }^{22}$ The $\mathrm{pH}$ measuring unit was calibrated at $37^{\circ} \mathrm{C}$ using standard buffer solutions of $\mathrm{pH} 6.70$ and 1.11 (Synectics Medical). After each run, calibration was repeated for assessment of the drift of the electrode.

All study subjects were admitted to our gastrointestinal unit at $5 \mathrm{pm}$, having fasted since $3 \mathrm{pm}$. The electrode was fluoroscopically placed in the gastric corpus $(8-10 \mathrm{~cm}$ below the cardia). Measurement began at $6 \mathrm{pm}$ and lasted for 24 hours. All subjects were ambulatory. The conditions were standardised with regard to meal timing and composition (dinner at $6 \mathrm{pm}$, breakfast at 8 am: lunch at noon). ${ }^{22}$ Water and unsweetened tea were allowed during meals. No antisecretory treatment and no antacids were allowed during the $\mathrm{pH}$ study. In the case of severe pain, duodenal ulcer patients were allowed to take antacids; but these $\mathrm{pH}$ recordings were excluded from the final analysis of gastric acidity. Normal daily activities were unrestricted. All

TABLE I Helicobacter pylori $(H P)$ status and characteristics of patients with gastritis, duodenal ulcer, and normal gastric mucosa

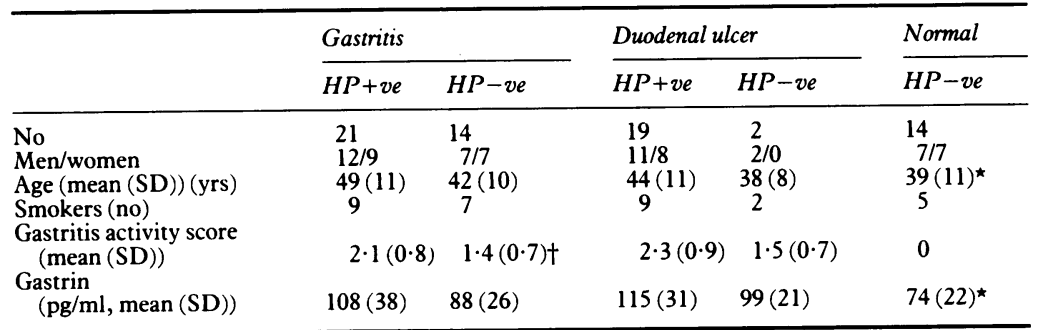

${ }^{\star} \mathrm{p}<0.05$ normal $v$ gastritis $\mathrm{HP}+\mathrm{ve}$

$t \mathrm{p}<0.05$ gastritis $\mathrm{HP}-\mathrm{ve} v$ gastritis $\mathrm{HP}+\mathrm{ve}$ study subjects marked their activities, meals, and special events in a diary card.

\section{DATA PROCESSING AND STATISTICS}

The $\mathrm{pH}$ measurements were stored every 4 seconds and the collected data were transferred to an IBM computer (AT 286). The recorded data were analysed for predefined time periods (total 24 hour: 6 pm-6 pm; evening: 6 pm-10 pm; night: 10 pm-6 am; morning: 6 am-12 noon; afternoon: 12 noon- 6 pm). ${ }^{22}$ Median $\mathrm{pH}$ and median hydrogen ion activity and interquartile ranges were calculated for individuals and groups. For graphical presentation the medians of $\mathrm{pH}$ values averaged over 10 minute periods were used. Differences between the different time periods of duodenal ulcer and gastritis patients and normal subjects were assessed by Wilcoxon's rank sum test. In addition, the integrated area under the curve (AUC) for each 24 hour $\mathrm{pH}$ profile was calculated using the trapezoidal rule. AUCs were compared using Wilcoxon's rank sum test. Probability values $\mathrm{p}<0.05$ were considered significant.

\section{GASTRIN ASSAY}

A fasting blood sample was obtained from the subjects at entry to the study for measurement of serum gastrin by a commercial radioimmunoassay (Dinabot Company, Tokyo, Japan; normal range: $49 \cdot 4-126 \cdot 2 \mathrm{pg} / \mathrm{ml}$ ). Serum gastrin concentrations of $H$ pylori positive patients and of uninfected patients were compared using Student's $t$ test.

\section{Results}

$H$ pylori status, gastric histology, and 24 hour acidity were studied in 35 gastritis patients, 21 duodenal ulcer patients, and in 14 subjects with normal gastric mucosa. $H$ pylori was identified in 21 of 35 patients with chronic active gastritis, and in 19 of 21 duodenal ulcer patients, but in none of those with normal gastric mucosa (Table I). Sex ratio and smoking habits were comparable within the three groups. Mean age was somewhat lower in $H$ pylori negative subjects; this difference reached statistical significance in normal subjects only (Table I). Gastritis scores were similar in infected gastritis and duodenal ulcer patients, but were significantly lower in uninfected gastritis patients. Fasting serum gastrin was lower in $H$ pylori negative patients, but this difference was only statistically significant in the normal subjects.

Median 24 hour hydrogen ion activity (interquartile range) was $21(8 \cdot 9-38.0) \mathrm{mmol} / \mathrm{l}$ in normal subjects and $23(11 \cdot 2-49 \cdot 0) \mathrm{mmol} / \mathrm{l}, 19$ $(7 \cdot 1-33 \cdot 1) \mathrm{mmol} / \mathrm{l}, 44(25 \cdot 1-63 \cdot 1) \mathrm{mmol} / \mathrm{l}$, and $36(31 \cdot 6-39 \cdot 8) \mathrm{mmol} / \mathrm{l}$ respectively in gastritis and duodenal ulcer patients with and without $H$ pylori infection. The 24 hour median $\mathrm{pH}$ profiles of patients with gastritis and duodenal ulcer are shown in the Figure. $H$ pylori infection did not have a significant effect on the pattern of the $\mathrm{pH}$ profiles in either patient group. However, the gastric $\mathrm{pH}$ was constantly lower in $H$ pylori positive duodenal ulcer patients compared with 

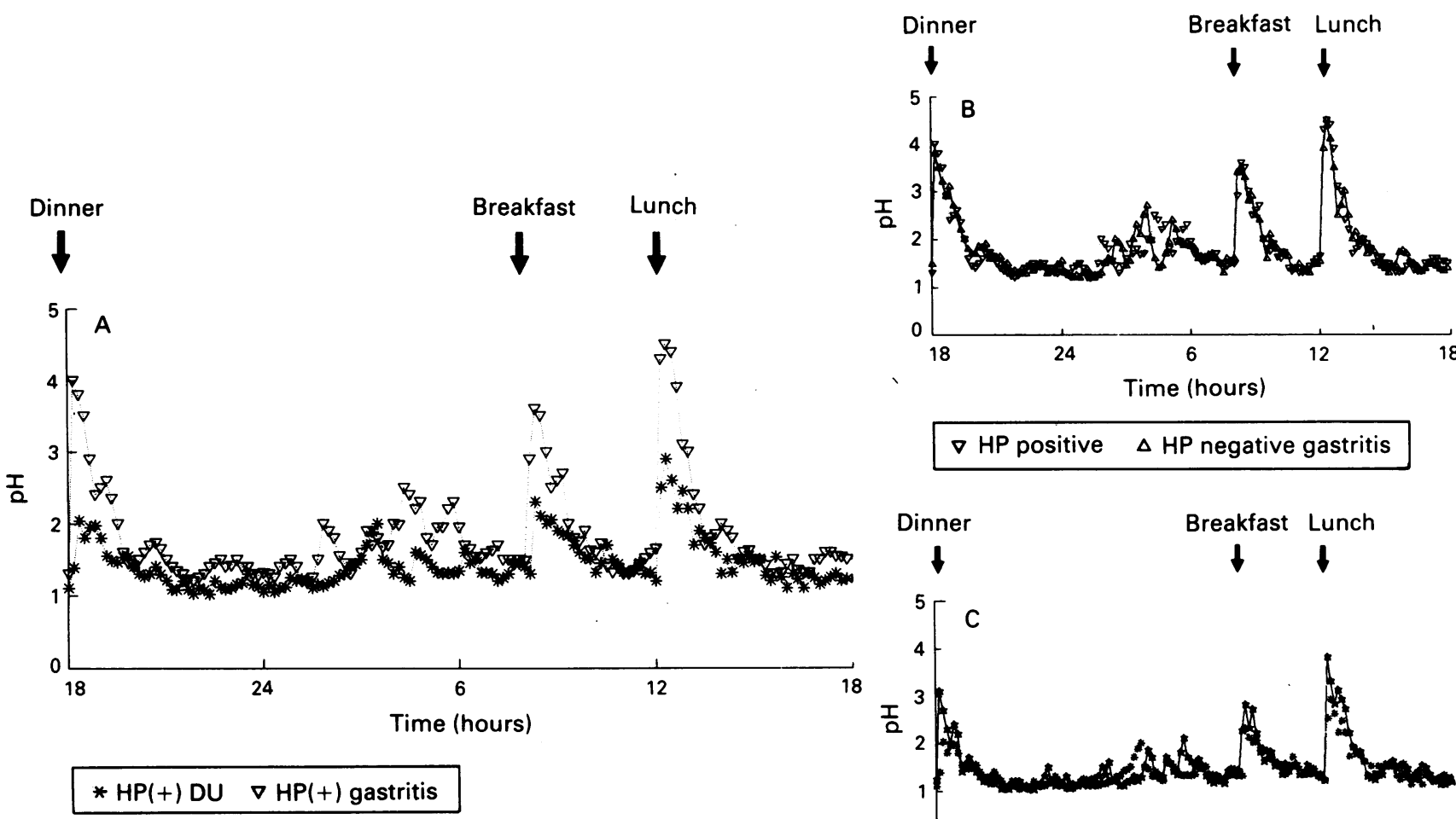

Median 24 hour $p H$ profiles of patients with Helicobacter pylori $(\mathrm{HP})$ positive duodenal ulcer $(D U)$ and $\mathrm{HP}$ positive gastritis $(A)$, HP positive and negative gastritis $(B)$, and $\mathrm{HP}$ positive and negative duodenal ulcer $(C)$.

$H$ pylori positive gastritis patients. This difference was most prominent during meals and during the nocturnal fasting period. The $\mathrm{pH}$ profile of the subject with normal gastric mucosa resembled that of the gastritis patients (not shown).

A quantitative analysis of the $\mathrm{pH}$ profiles showed that the intragastric $\mathrm{pH}$ was significantly lower in duodenal ulcer patients during all predefined time periods when compared with gastritis patients and normal subjects (Table II and III). The integrated AUCs of the 24 hour $\mathrm{pH}$ profiles of the infected duodenal ulcer patients were significantly lower than those of the $H$ pylori positive and negative gastritis patients and those of the normal subjects as well. However, the AUCs were similar in subjects with normal

TABLE II Median $p H$ and interquartile ranges for different time periods in gastritis and duodenal ulcer patients and subjects with normal gastric mucosa, and influence of $\mathrm{H}$ pylori (HP) infection

\begin{tabular}{|c|c|c|c|c|c|}
\hline & 24 hour & Evening & Night & Morning & Afternoon \\
\hline & $6 p m-6 p m$ & $6 p m-10 p m$ & $10 \mathrm{pm}-6 \mathrm{am}$ & $6 a m-12 p m$ & $12 p m-6 p m$ \\
\hline Norm & 1.67 & 8 & 50 & $1 \cdot 72$ & .68 \\
\hline s(HP+) & 1.6 & $\begin{array}{l}1.60- \\
1.89\end{array}$ & $\begin{array}{l}1.30- \\
1.50\end{array}$ & $\begin{array}{l}(1.35- \\
1.69\end{array}$ & $1 \cdot 6$ \\
\hline & $(1 \cdot 31-1.95)$ & $(1 \cdot 56-3 \cdot 20)$ & $(1.35-1.98)$ & $(1.51-1.99)$ & $(1 \cdot 50-2 \cdot 05)$ \\
\hline $\begin{array}{l}\text { Gastritis (HP-) } \\
(n=14)\end{array}$ & 1.72 & 1.96 & 1.57 & $1 \cdot 74$ & $\begin{array}{l}1.73 \\
(1.52\end{array}$ \\
\hline $\begin{array}{c}(n=14) \\
\text { Duodenal ulcer }\end{array}$ & $1 \cdot 36$ & $\begin{array}{l}1.63 \\
1.42\end{array}$ & $\begin{array}{l}(1.37 \\
1.25\end{array}$ & $\begin{array}{l}(1.61 \\
1.47\end{array}$ & $\begin{array}{l}(1.52 \\
1.49\end{array}$ \\
\hline III & $(1 \cdot 20-1 \cdot 60)$ & $(1 \cdot 22-1 \cdot 58)$ & $(1 \cdot 10-1 \cdot 44)$ & $(1 \cdot 32-1 \cdot 66)$ & $(1 \cdot 24-1 \cdot 69)$ \\
\hline $\begin{array}{l}\text { Duodenal ulcer } \\
(\text { HP }-)(\mathbf{n}=2)\end{array}$ & $\begin{array}{l}1.45 \\
(1.40-1 \cdot 50)\end{array}$ & $\begin{array}{l}1 \cdot 50 \\
(1 \cdot 40-1 \cdot 60)\end{array}$ & $\begin{array}{l}1 \cdot 35 \\
(1 \cdot 20-1 \cdot 50)\end{array}$ & $\begin{array}{l}1 \cdot 55 \\
(1 \cdot 40-1 \cdot 70)\end{array}$ & $\begin{array}{l}1.55 \\
(1.50-1.60)\end{array}$ \\
\hline
\end{tabular}

${ }^{\star} \mathrm{p}<0.01$ or less, DU vs normal and gastritis for any time period; of $19 \mathrm{pH}$ were excluded due to violation of the protocol resulting in $17 \mathrm{pH}$ measurement. tTotal range. gastric mucosa and both gastritis subgroups, showing that there is no difference in the acidity profiles of $H$ pylori positive and negative gastritis patients.

\section{Discussion}

This study shows that intragastric acidity is essentially the same in patients with chronic active gastritis, irrespective of their $H$ pylori status, and in subjects with normal gastric mucosa. In addition, our study confirms previous findings of an increased gastric acidity in duodenal ulcer patients. ${ }^{22-27} H$ pylori negative duodenal ulcers were very rare, allowing $\mathrm{pH}$ monitoring in only two patients who showed acidity similar to the $H$ pylori positive duodenal ulcer patients.

In agreement with previous work, ${ }^{6913}$ our $H$ pylori positive patients had higher fasting serum gastrin levels than the uninfected subjects. It is now well established that $H$ pylori infection is associated with inappropriate hypergastrinaemia

TABLE III Area under the curve of the 24 hour $\mathrm{pH}$ profiles of normal subjects and of gastritis and duodenal ulcer patients

\begin{tabular}{|c|c|c|c|c|c|}
\hline & \multirow{2}{*}{ Normal } & \multicolumn{2}{|l|}{ Gastritis } & \multicolumn{2}{|c|}{ Duodenal ulcer } \\
\hline & & $\overline{H P(+)}$ & $H P(-)$ & $H P(+)$ & $H P(-)$ \\
\hline $\begin{array}{l}\text { Mean } \\
\text { SD }\end{array}$ & $\begin{array}{r}2682 \\
527\end{array}$ & $\frac{2643 \dagger}{485}$ & $\begin{array}{r}2712 \\
622\end{array}$ & $\underset{555}{2074^{\star}}$ & $\begin{array}{r}2184 \\
550\end{array}$ \\
\hline
\end{tabular}

* $\mathrm{p}<0 \cdot 05$, duodenal ulcer $\mathrm{HP}(+) v$ normal and all gastritis groups tnot significant, gastritis $\mathrm{HP}(+) v$ gastritis $\mathrm{HP}(-)$ and normal subjects. 
and that its eradication results in a lowering of the fasting and meal-bombesin stimulated gastrin concentration. ${ }^{69111+28-30}$ However, the mechanism by which chronic infection of the gastric mucosa with $H$ pylori results in increased gastrin is not known. Moreover, the consequences of $H$ pylori associated hypergastrinaemia on gastric acidity are unknown.

It has recently been suggested by Levi et $a l^{6}$ that $H$ pylori induced hypergastrinaemia may cause duodenal ulcer by an increase in gastric acid secretion. There are currently limited data relating gastric acidity to the presence of chronic $H$ pylori infection. Levi et $a l^{6}$ reported that the basal and peak acid outputs in response to pentagastrin were higher in $H$ pylori positive duodenal ulcer patients compared with $H$ pylori negative patients. In contrast, Hui et al observed similar maximal acid output in $H$ pylori positive and negative duodenal ulcer patients. ${ }^{31}$ Brady et al could not detect a constant relationship between $H$ pylori and gastric acid secretion.? Smith et al reported that there was no significant difference in the median integrated 24 intragastric acidity between $H$ pylori positive and $H$ pylori negative asymptomatic healthy subjects despite the presence of an inappropriate hypergastrinaemia. ${ }^{12}$ Similarly, Goldschmiedt et al showed that in healthy humans $H$ pylori infection was associated with hypergastrinaemia, but not with gastric acid hypersecretion. ${ }^{13}$

This is the first study which concurrently investigates 24 hour acidity and $H$ pylor infection in gastritis and duodenal ulcer patients. In agreement with recent studies, ${ }^{12}{ }^{13}$ our $\mathrm{pH}$ data show that gastric acidity is similar in subjects with normal gastric mucosa and in gastritis patients, whether or not they have $H$ pylori infection. In this study, gastric acidity was assessed by ambulatory long term intragastric $\mathrm{pH}$ monitoring, this method ignores the volume of acid output. Smith et al measured gastric acidity using a gastric aspiration technique. ${ }^{12}$ In contrast, Goldschmiedt et al determined the basal and stimulated acid secretion rate. ${ }^{13}$ Since the different acid measuring techniques all gave the same results, it is tempting to suggest that chronic $H$ pylori infection does not affect gastric acid secretion despite the presence of hypergastrinaemia. However, it is possible that hypergastrinaemia has to persist for many years to induce an increase in the parietal cell mass which would then produce the hyperacidity characteristic of duodenal ulcer disease. This hypothesis cannot be clarified further in our study since patients with duodenal ulcer disease without $H$ pylori infection were extremely rare. Our $\mathrm{pH}$ data from the two $H$ pylori negative duodenal ulcer patients do not allow a definite conclusion.

Although there is accumulating evidence that $H$ pylori infection is a major factor in the pathogenesis of duodenal ulcer disease, several questions regarding the putative link between gastric acidity and $H$ pylori remain unresolved. Duodenal ulcer patients, as a group, secrete more acid than normal subjects, but more than half of duodenal ulcer patients have normal acid secretion..$^{32} 33$ On the other hand, almost all duodenal ulcer patients have gastric $H$ pylori infection and one would therefore expect hyperacidity in almost all duodenal ulcer patients. The prevalence of $H$ pylori infection increases with age, amounting to about $40 \%$ in whites in the fifth decade of life and about $70-80 \%$ in the eighth decade.$^{3+}$ On the other hand, the lifetime prevalence of duodenal ulcer disease is less than $10 \%$. If one assumes that $H$ pylori associated hypergastrinaemia is responsible for the hyperacidity in duodenal ulcer disease, then the question of why most $H$ pylori infected people do not develop hyperacidity or duodenal ulcer, or both, despite the presence of hypergastrinaemia arises. Finally, McColl et al did not observe a decrease in gastric acidity and gastric acid output seven months after eradication of $H$ pylori in duodenal ulcer patients despite a sustained fall in gastrin. ${ }^{35}$

In conclusion, our study shows that gastric acidity is similar in subjects with normal gastric mucosa and in $H$ pylori positive and negative gastritis patients. Duodenal ulcer patients have increased gastric acidity. Based on these results, we assume that chronic $H$ pylori infection does not change intragastric acidity in most infected subjects.

Part of this work was presented at the 91st Meeting of the American Gastroenterological Association in San Antonio, on May 14,1990 , and was published in abstract form (Gastroenterology 1990; 98: A145).

1 McKinlay AW, Upadhyay R, Gemmell CG, Russel RI Helicobacter pylori: bridging the credibility gap. Gut 1990 31: 940-5.

2 Peterson WL. Helicobacter pylori and peptic ulcer disease. $N$ Englf Med 1991; 324: 1043-8.

3 Coghlan JG, Humphries H, Dooley C, Keane C, Gilligan D, McKenna D, et al. Campylobacter pylori and recurrence of duodenal ulcers - a 12-month follow-up study. Lancet 1987; dii: $1109-11$.

4 Marshall BJ, Goodwin CS, Warren JR, Murray R, Blincow ED, Blackborun SJ, et al. Prospective double-blind trial of duodenal ulcer relapse after eradication of Campylobacte pylori. Lancet 1988; ii: 1437-42.

5 Rauws EAJ, Tytgat GNJ. Cure of duodenal ulcer associated with eradication of Helicobacter pylori. Lancet 1990; 335 1233-5.

6 Levi S, Beardshall K, Haddad G, Playford R, Ghosh P, Calam J. Campylobacter pylori and duodenal ulcers: the gastrin link. Lancet 1989; i: 1167-8.

7 Brady CE, Hadfield TL, Hyatt JR, Utts SJ. Acid secretion and serum gastric levels in individuals with Campylobacter pylori. Gastroenterology 1988; 94: 923-7.

8 Montbriand JR, Appelman HD, Cotner EK, Nostrant TT Elta GH. Treatment of Campylobacter pylori does not alter Elta GH. Treatment of Campylobacter pylori does not alter

9 Oderda G, Vaira D, Holton J, Ainley C, Altare F, Ansaldi N. Amoxycillin plus tinidazole for campylobacter pylor gastritis in children: assessment by serum IgG antibody pepsinogen I, and gastrin levels. Lancet 1989; i: 690-2

10 Wagner S, Schüler A, Gebel M, Freise J, Schmidt FW Campylobacter pylori and acid secretion, (letter). Lance 1989; ii: 562 .

11 Graham DY, Opekun A, Lew GM, Evans DJ, Klein PD, Evans DG. Ablation of exaggerated meal-stimulated gastrin release in duodenal ulcer patients after clearance of Helicobacter (Campylobacter) pylori infection. Am $\mathcal{F}$ Gastroenterol 1990; 85: 394-8.

12 Smith JTI Pounder RE, Nwokolo CU, Lanzon-Miller S, Evans DG, Graham DY, et al. Inappropriate hyperEvans DG, Graham DY, et al. Inappropriate hypergastrinaemia in asymptomatic healthy sub

13 Goldschmiedt M, Karnes WE, Feldman M. Relationship between Helicobacter pylori and gastric acid secretion/ serum gastrin concentrations in healthy humans. Gastroenterology 1990; 98: A50.

14 Graham DY, Opekun A, Lew GM, Klein PD, Walsh JH Helicobacter pylori-associated exaggerated gastrin release in duodenal ulcer patients. The effect of bombesin infusion an urea ingestion. Gastroenterology 1991; 100: 1571-5.

15 Morris A, Nicholson G. Ingestion of Campylobacter pyloridis causes gastritis and raised fasting gastric $\mathrm{pH}$. Am $\mathcal{f}$ Gastroenterol 1987; 83: 192-9.

16 Peterson W, Lee E, Skoglund M. The role of Campylobacter pyloridis in epidemic gastritis with hypochlorhydria. [Abstract]. Gastroenterology 1987; 92: 1575 .

17 Graham DY, Smith JL Alpert LC Yoshimura HH. Jatrogenic Can achlorhydria. Am 7 Gastroenterol 1988; 83: 974-80. 
18 Barthel JS, Westblom TU, Havey AD, Gonzalez F, Everett ED. Gastritis and Campylobacter pylori in healthy, asymptomatic volunteers. Arch Intern Med 1988; 148: 1149-51.

19 Mullin GE, Kalloo AN. Does Helicobacter pylori infection affect gastric acid secretion? [Abstract]. Gastroenterolog 1990; 98: A92.

20 Wagner S, Freise J, Bär W, Fritsch S, Schmidt FW. Epidemiologie und Therapie der Campylobacter-pyloriInfektion. Disch Med Wochenschr 1989; 114; 407-13.

21 Wagner S, Gebel M, Haruma K, Bär W, Lange P, Freise J, et al. Bismuth subsalicylate in the treatment of H2-blocker et al. Bismuth subsalicylate in the treatment of H2-blocker resistant duodenal

22 Wagner S, Gladziwa U, Gebel M, Schüler A, Freise J, Schmid FW. Circadian pattern of intragastric acidity in duodena ulcer patients: a study of variations in relation to ulcer activity. Gut 1991; 32: 1104-9.

23 Feldman M, Richardson CT. Total 24-hour gastric secretion in patients with duodenal ulcer. Comparison with normal subjects and effects of cimetidine and parietal cell vagotomy. Gastroenterology 1986; 90 : $540-4$.

24 Blair AJ, Feldman M, Barnett C, Walsh JH, Richarson CT. Detailed comparison of basal and food-stimulated gastric acid secretion rates and serum gastrin concentrations in duodenal ulcer patients and normal subjects. $\mathcal{F}$ Clin Invest 1987; 79: 582-7.

25 Lanzon-Miller S, Pounder RE, Hamilton MR, Ball S, Chrono NAF, Raymond F, et al. Twenty-four hour intragastric acidity and plasma gastrin concentration in healthy subjects and patients with duodenal or gastric ulcer or pernicious anemia. Aliment Pharmacol Therap 1987; 1: 225-37.

26 Savarino V, Mela GS, Scalabrini P, Sumberaz A, Fera G, Celle G. 24-hour study of intragastric acidity in duodenal ulcer patients and normal sub pH-metry. Dig Dis Sci 1988; 33: 1077-80.
27 Merki HS, Fimmel CJ, Walt RP, Harre K, Röhmel J, Witze L. Pattern of 24 hour intragastric acidity in active duodena ulcer disease and in healthy subjects. Gut 1988; 29: 1583-7.

28 McColl KEL, Fullarton GM, Nujumi AM, Macdonald AM Brown IL, Hilditch TE. Lowered gastrin and gastric acidity after eradication of Campylobacter pylori in duodenal ulcer. Lancet 1989; ii: 499-500.

29 Chitrallu RS Neithercut WD Macdonald AMI, McColl KEL. The effect of increasing Helicobacter pylori ammonia production by urea infusion on plasma gastrin concentraproduction by urea infusion

30 El Nujumi AM, Dorrian CA, Chittajallu RS, Neithercut WD McColl KEL. Effect of inhibition of Helicobacter pylor urease activity by acetohydroxamic acid on serum gastrin in duodenal ulcer subjects. Gut 1991; 32: 866-70

31 Hui WM, Lam SK, Chau PY, Ho J, Lui I, Lai CL, et al. Persistence of Campylobacter pyloridis despite healing of duodenal ulcer and improvement of accompanying duodenitis and gastritis. Dig Dis Sci 1987; 32: 1255-60.

32 Feldman $M$, Richardson CT, Lam SK, Samloff IM. Comparison of gastric acid secretion rates and serum pepsinogen I and II concentrations in occidental and orienta pepsinogen 1 and II concentrations in occidental and orient

33 Wolfe MM, Soll AH. The physiology of gastric acid secretion. NEngl F Med 1988; 319: 1707-15.

34 Graham DY, Malaty HM, Evans DG, Evans DJ, Klein PD, Adam E. Epidemiology of Helicobacter pylori in an asymptomatic population in the United States. Effect of age, race, and socioeconomic status. Gastroenterology 1991; 100: 1495-501.

35 McColl KEL, Fullarton GM, Chittajalu R, El Nujumi AM, Macdonald MI, Dahill SW, et al. Plasma gastrin, daytime intragastric $\mathrm{pH}$, and nocturnal acid output before and at 7 months after eradication of duodenal ulcer subjects. Scand $\mathcal{F}$ Gastroenterol 1991; 26: 339-46. 